水文・水源学 会誌

J. Japan Soc. Hydrol \& Water Resour.

Vol. 7. No. 3 (1994) PP. 223-227

\title{
タクラマカン砂漠地域の水文環境
}

\section{Hydrological Conditions in and around the Taklamankan Desert}

\author{
王良瑋*・曲耀光* \\ Wang Lian Way • Qu Yao Gouang \\ 米谷恒春** \\ Tsuneharu YONETANI
}

\author{
中国科学院 蘭州冰川凍土研究所 \\ Lanzhou Institute of Glaciology and Geocryology. Academia \\ 科学技術庁 防災科学技術研究所 \\ National Research Institute for Disaster Prevention and Earth Science
}

\section{I 、はじめに}

1980年代の初めにアフリカのサヘール地方の干ば つとこれによる難民の発生がきっかけとなって,人 間活動が関与した砂漠化が国際的な関心事となり, 現在,この問題は多くの国が取り組んでいる地球㻴 境問題の一つになっている. 国土の約 $25 \%$ が年降水 量 $250 \mathrm{~mm}$ 以下の乾燥地域に属し, コビ砂漠, タクラ マカン砂漠等の広大な砂漠を有する中国では, 砂漠 の自然環境特性を明らかにするための調査, 砂の固 定技術などの国土保全のための技術開発, 等を実施 する研究機関として中国科学院蘭州沙漠研究所 （1959年に北京の中国科学院地理研究所砂漠研究室から 発展), 中国科学院新㩊生物土塆沙漠研究所(1963年設 立)を設け, 古くから砂漠に関連する研究を推進して いる. 当然のことながら, 乾燥地域における水資源,
水文状態に係る問題の解明は重要な研究分野になっ ている.

現在, 中国で砂漠地域での水文に関連する主要 な問題法，(1)河川上流のダム設置にともなう中・下 流域での流量の減少, 水䆩悪化, 湖水の枯渴, 植生 の破壊等の砂漠化，(2)灌溉に必要以上の水の供給が 地下水位の上昇を引き起こすことによって生じる土 壤の塩分集程, (3)地下水の多量なポンプアップによ る局所的な地下水位の低下による植生の破壊, (4)長. 期的かつ総合的な水利用計画の欠如, である(Gao et $a l ., 1992)$.なお, 同じ報告によれば(1)に関連する不 合理的な水資源の利用により砂漠化した土地は今ま でに約39,000kに達している。

本報告では国タクラマカン砂漠地域の水文環境 について，中国でなされた調査・研究および科学技 術庁科学技術振興調整費による日中国際共同研究砂
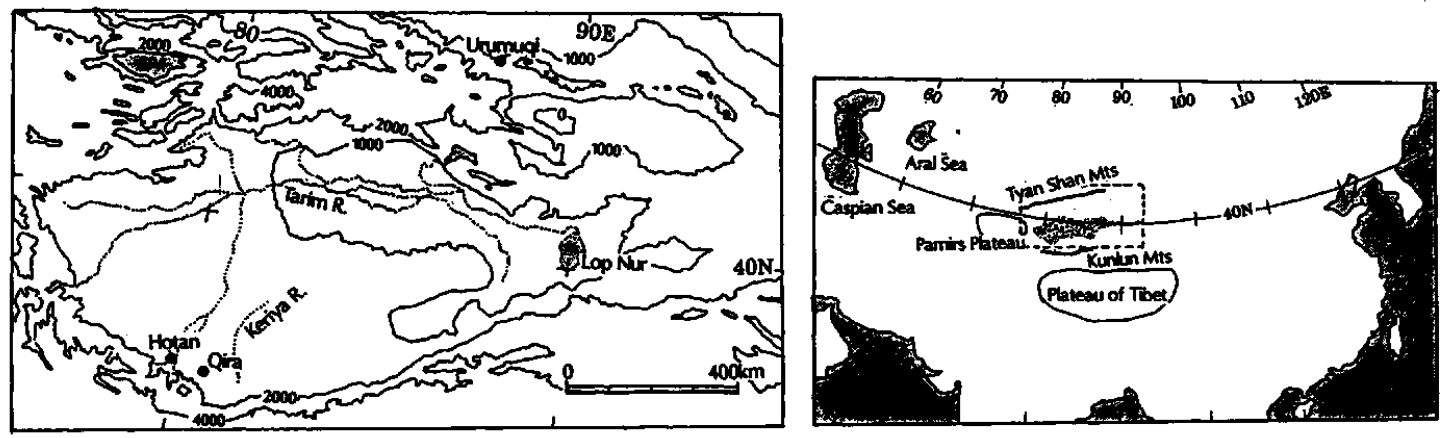

图一1 タクラマカン䂗璂の位置と地形の概要

\footnotetext{
"Lanzhou Institute of Glaciology and Geocryology, Academia Sinica 苚州市東楠西路174号73000, 中国 **防災科学技術研究所 気圈 - 水圈地球科学技街研究部 干305 茨城県天王台3-1

Atmospheric and Hydrospheric Science Division, NIED, Tennodai 3-1, Tsukuba 305, Japan
} 
漠化機構の解明研究の一環として筆者らが実施した 観測で今までに得られた成果に基づき，その概要を 説明する.

\section{II. 地形状況}

タクラマカン砂漠はユーラシア大陸の中央部, 東 経77〜94度, 北緯37〜42度の間にあるタリム盆地の 大部分を占め，面䅡約 30 万 $\mathrm{kn}^{\mathrm{m}}$ を有している，中心部 ては高さ100〜 $200 \mathrm{~m}$, 長さ $10 \mathrm{~km}$ 程度の砂丘が連なる 大砂漠である．地形的には西が高く東が低く，標高 は, 西から南西部分が $1,200 \sim 1,400 \mathrm{~m}$, 東から北東て は815〜875mであり, 平均で1,000mとなる (図一1 参照).

タリム盆地は東側を除く三方が山脈に囲まれてい る. 北側は平均海拔 $3,500 \mathrm{~m}$ のテンシャン (Tyan Shan)山脈が1,700kmにわたって在り，西側はパミー ル高原が，南側はコンロン(Kunlun)山脈がチベット 高原との間に横たわっている.コンロン山脈はテン シャン山脈より高く,勾配も急であり，6,000m級の 高山が連なっている. テンシャン山眽の南斜面では 雪線が3,500〜4,000mの範囲にあり，西の方には大 きな水河があり，積雪量が多い．また，コンロン山 脈の北斜面では雪線は約 $5,000 \mathrm{~m} に$ あり,一般に, $5,500 \mathrm{~m}$ 以上の高山に米河が分布している.

砂漠の中心から周辺の山に向かって四つの自然景 観带が認められる. 即ち, 砂漠・塩湖帯, オアシス

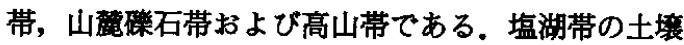

はアルカリ土壤であり, 水質は高い硬度 (硬水)を示 している. 従って, アルカリ耐性の植物だけが生育 可能である. タリム盆地東端(タリム河が終わる辺り) 一帯が塩湖帯の景観を呈している.オアシス帯ては, 地下水位は深くはなく，水質も淡水または弱硬水で ある. 生活圈の形成と農業活動がこの地帯の特色で ある. 山䇹䃯石帯では多数の磷の存在と植生が希て あること，深い地下水位が特色となっている. 最外 縁の高山帯では植生, 土埕, 水文状況が高さによっ て変化している.テンシャン山脈の西部で高さによ る変化が最も顕著でありそこでは高度が増すに 従って高山森林加ら草原へと変わっている.

\section{III. 気候状況}

タリム盆地は大陸内部にあり，かつ高山に囲まれ ているため，典型的な大陸性気候を呈している，千 ベット高原とコンロン山脈は南方インド洋からの高 温多湿な季節風の進入を妨げている.テンシャン山 脈は北極海の湿った気団の南下を困難としている. また, タリム盆地の東方にはいくつかの山々があり, タリム盆地が太平洋から遠く隔たっていることと相 まって，太平洋気団の影慗を弱めている，夕リム盆 地東緑の低い地形に沿って蒙古，シベリアからの乾 燥した気団が進入する。このような地形の影蠁のた め, 気候条件は以下のように盆地内は非常に乾燥し ており, 山間部では比較的降水量が多く, 氷河が存 在している.

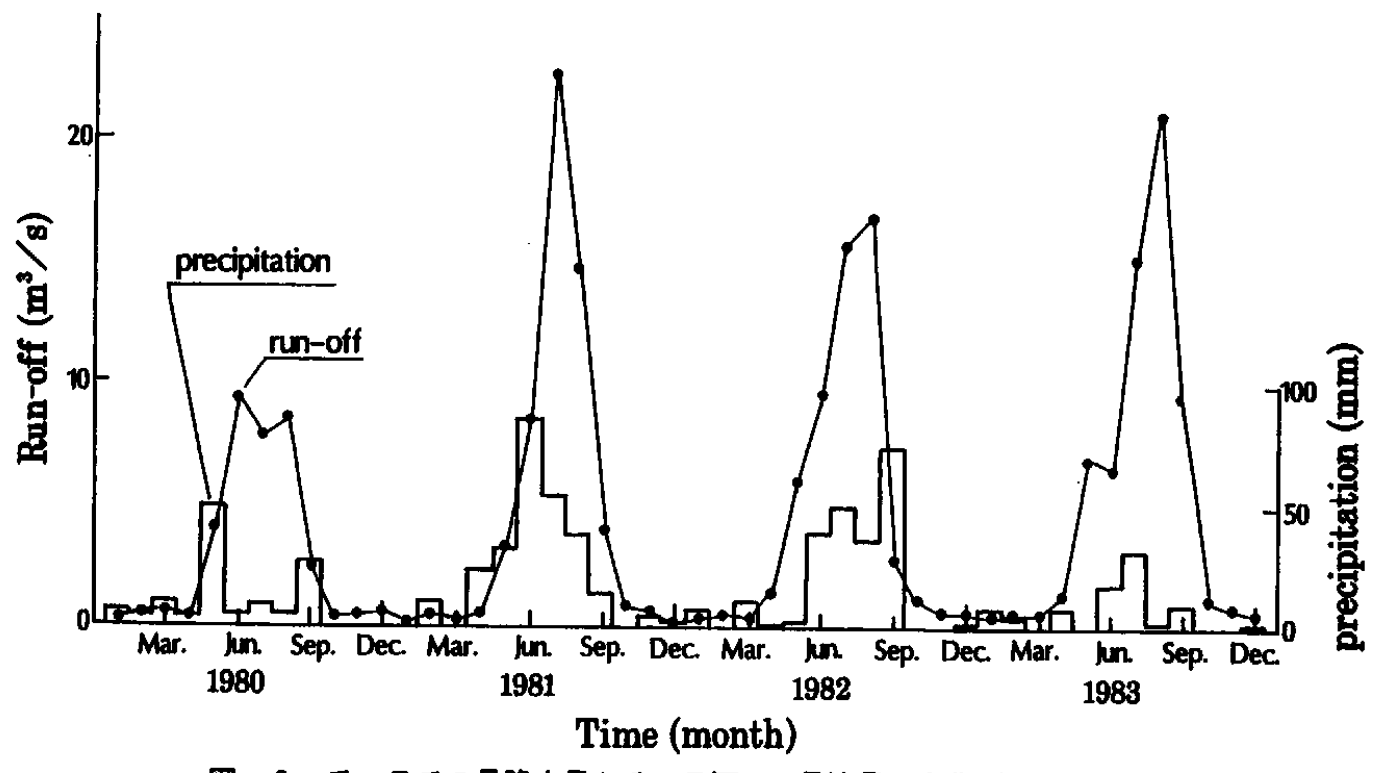

図ー2 チーラでの月降水量とチーラ河での月流量の变化（1980〜1983） 
1) 降水量はタクラマカン砂漠から周辺の山間部 へすすむに従って著しく増加している. 砂漠の中心 部及び標高の低い東部地区では平均年降水量が $10 \mathrm{~mm}$ 以下であり, 周辺の高山地域では $400 \mathrm{~mm}$ 以上になって いる. 降水量の月変化を示す例として, タクラマカ ン砂漠南縁のオアシスのチーラ (Qira, 位固は图一 1 参照) での1980〜1983年の月降水量の変化をチーラ 河の月流出量の変化とあわせて示す (図一2 参照). これからも分かるように，降水は $6 \sim 9$ 月に集中し ている.また，寒候期の河川流量は非常にわずかで ある.

2) 平均気温は砂漠地区て高く山岳地帯で低い. 砂漠地域での平均気温は $11^{\circ} \mathrm{C}$, 日較差の平均は $30^{\circ} \mathrm{C}$, 年最高気温と年最低気温の差は50〜 $60^{\circ} \mathrm{C}$ に達する.

3) 蒸発血で測定された蒸発量は通常 $2,100 \mathrm{~mm}$ 時には $3,000 \mathrm{~mm}$ 超えることがある。乾燥し, 気温が 高いので蒸発が盛んであり, 蒸発がポンプアップ等 の人工的消費を除くと唯一の地下水隇少要素である.

\section{N. 水文環境}

降水量が少ないタりム盆地に流入する河川の源は 山間部であり, 北東部は外に向かって開けていると はいえタリム盆地より標高が高いので，閉鎖的な内 陸水系となっている.この地を流れる河川は幾十と あるが最大のものはタリム (Tarim) 河である.タリ ム河はアクス河, ヤルチャン河, ホータン河, カシュ ガル河などの大きな河川を合わせ, タクラマカン砂 漠の北縁に沿ってタリム盆地を東から西へ横断し， その後南下してタイテマ湖に注ぎ込んでいる中国最 大の内陸水系である. 東部にはタリム河以外にコン ジェ河, チャミチェン河の大河川が流れており,こ れはそれぞれロブボとタイテマ湖に流れ込んでいる。
この他に砂漠内で消えている河川が多数ある．後で その流出状況などをやや詳しく示すチーラ河もその 一つである.

李・趙（1965）によれば，氷河を源とする河川は約 40あり, 河川長は $100 \sim 1,000 \mathrm{~km}$, 平均流量は 3〜190 $\mathrm{m}^{3} / \mathrm{sec}$, 年間流量 1 ～60億的となっている.タクラマ

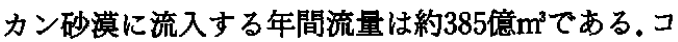
ンロン山脈を起源とする河川は約20，これらがもた らす年間水量は 160 億 $\mathrm{m}^{3}$ ，砂漠に流入する総流量の 42\%を占め，テンシャン山脈を起源とする河川は約 12, これらがもたらす年間水量は 168 億 $\mathrm{m}^{3}$ ，全体の 44\%を占めている. パミール高原を起源とする河川 は 4 ，これらがもたらす年間流量は約 45 億 $\mathrm{m}^{3}, 12 \%$ を占め, アルキンサンを起源とする河川は 4 ，これ らがもたらす年間流量は約 12 億 $\mathrm{m}^{3}, 4 \%$ を占めてい る.

周辺の山間部の地下水を源とする河川も多くある. これら河川の年間流量の総計は約 23 億 $\mathrm{m}^{3}$ である.こ のような河川は西部に多く前記総流量の $48 \%$ を占め, ついで26\%を占めるテンシャン山脈地区， $21 \%$ を占 めるコンロン山脈地区となる.アルキンサン地区て は $4 \%$ 程度である。

山地に降雨があると急激な河川の増水をもたらす が，高山の水河および積雪の融解によるものは夏季 に流量が著しく増加するという影著な季節変化を示 す. 图一 3 に亦河を起源とする河川と地下水を起源 とする河川の典型的な流量の季節变化を示す，地下 水を起源とする河川では氷河を起源とする河川ほど 季節変化が激しくなく，夏の流量が少ない川もある. タクラマカン砂漠が非常に広大なこともあり，水 文過程, 地下水形成過程, 地下水量などの調查は多 くの困難を伴う仕事である．現在までのところ，タ
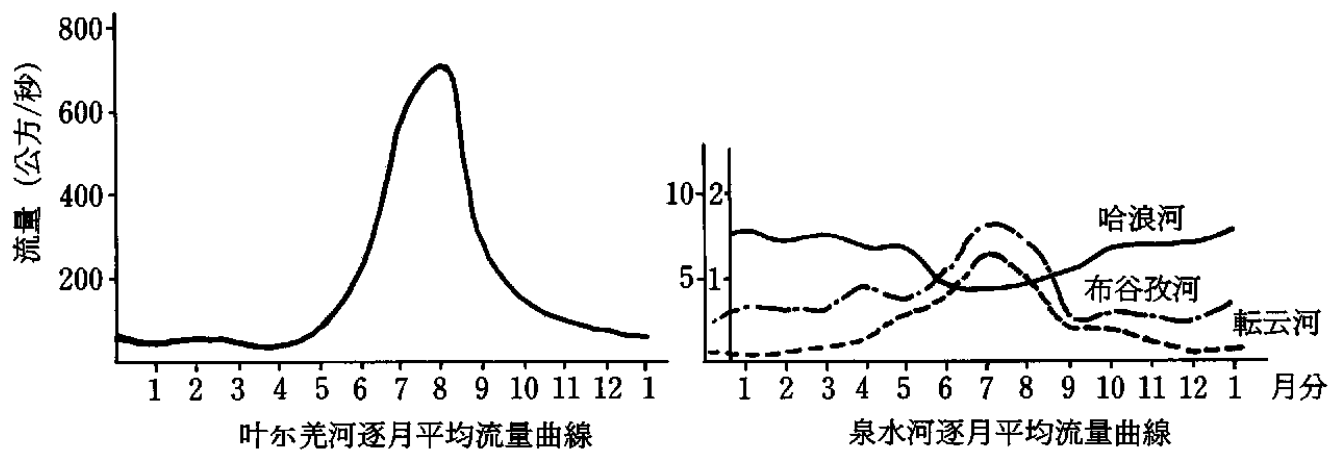

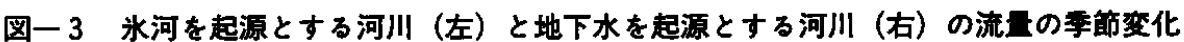
(李・趙，1965による) 
クラマカン砂漠の水収支についての詳しい計算はな されていないが，概略次の通りと考えられている. 前述の通り，タクラマカン砂漠に山間部から流入す る水量の総計は年間408億的である.周辺の山間部は 第四紀の地質からなっているので地下水が形成され 易く,山間部から流入する流量の約 $1 / 2 か ゙$ 地下水にな

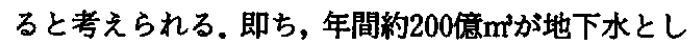
て補給され，同量が蒸発していることになる.

中国科学院などによる調查結果によるとタクラマ カン砂漠の地下水資源は 8 兆トンであることが, 最 近, 報道された (THE21, 1993)。つまり,タクラマ カン砂漠の下に, $200-300 \mathrm{~m}$ の首厚をもつ带水層が あり, 8 兆トンもの地下水が埋蔵されていると推察 されている，地下水涵養が報告されているように 年間200億卜ンとすれば，滞留時間は 400 年というこ とになる.一方, 我々がチーラで行った揚水試験に より評価した透水係数等を用いて, 源流から砂漠ま で到達時間を評価すると700時間弱となった.これ らの数値はそれなりの整合性が保たれているように 思われるが，確かなことを言うにはさらなるデー夕 の集䄼が必要であろう.

\section{V. チーラ河の流出特性}

この節では, 全長 $100 \mathrm{~km}$ 強, 流域面稜約 $2,000 \mathrm{kr} て ゙$, 源流域に隶河 (写真) を有するチーラ河の流出特性に ついて，既に発表されたもの(Yonetani et al ., 1993) に最近の成果を追加して記す。

既に図一 3 に示したように，他の水河を起源とす る河川と同じように; 寒候期の流量は非常に少なく， 降水の多い夏を中心に河川流量が多くなるという影 著な季節変化を示している. しかしながら，降水量 と流量の相関は必ずしも明確ではい。图一4は 1980～1983年のデータに基づく月降水量と月流出高

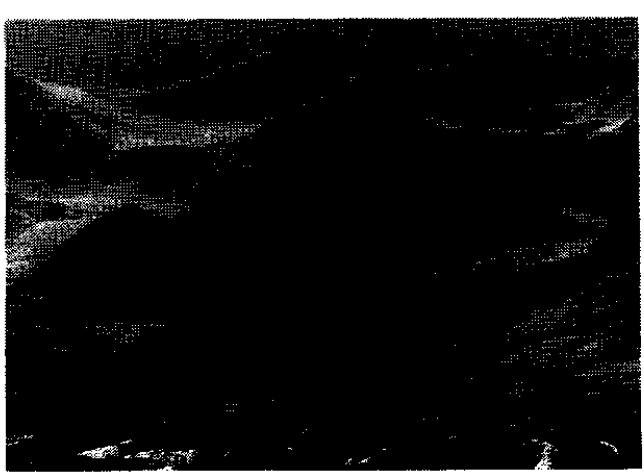

写共 チーラ河票流城の水河
の関係を示している．図から月流出高が降水量によ らず 7,8 月に最も多く，次いで $5 ， 6 ， 9$ 月に多 いことが読み取れる。

チーラ河中流域, 標高 $2,600 \mathrm{~m} て ゙$ 測定した河川流量 と気温の時間変化を 10 月と6月末の各々数日につい て図一5に示す，ほとんど全ての日で気温は頑著な 日変化を示しており, 日較差は $15^{\circ} \mathrm{C}$ 程度になってい る.ところで，最高気温が約 $15^{\circ} \mathrm{Cであった} 10$ 月のと さには流量はほとんど変化していない。一方, 最高 気温が $20^{\circ} \mathrm{Cを}$ 越える日があった 6 月末では，最高気

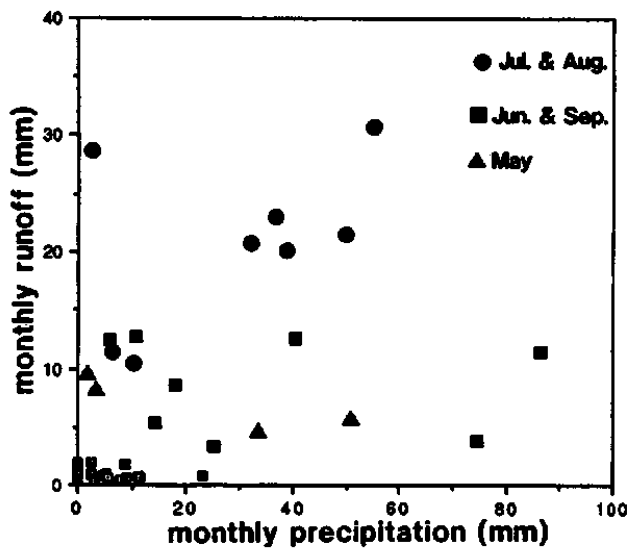

図一4 チーラ河の月降水旦, 月流出高の相関 図 (1980 1983)
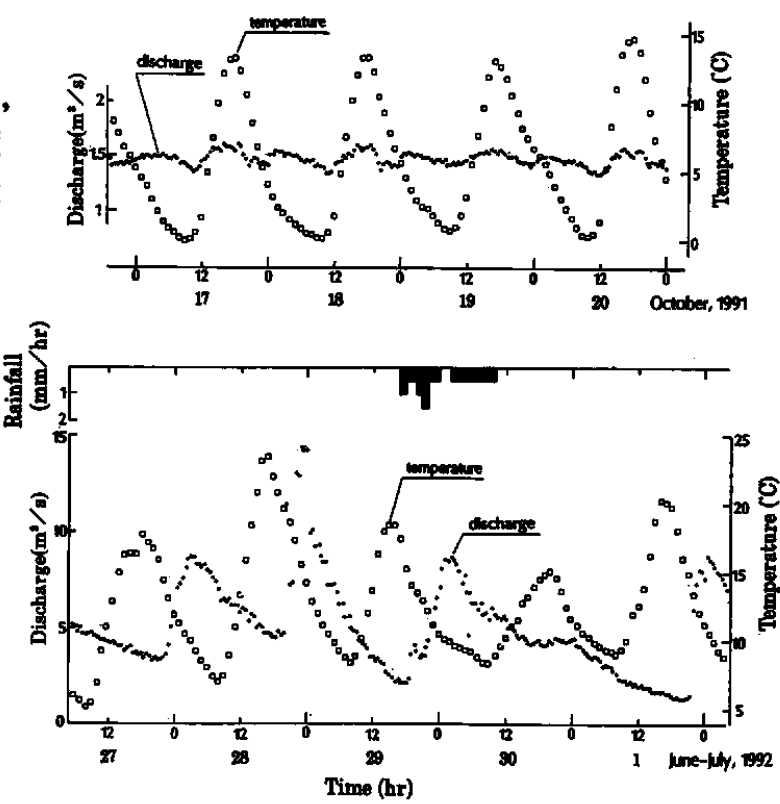

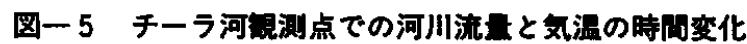


温が $15^{\circ} \mathrm{C}$ に達しなかった 30 日を除いて, 流量も顥著 な日変化を示している，そのピークは，気温が最高 値を示す 16 時頃より 8 時間後の 0 時頃 (北京時間) に 記されている。

この河川流量の時間変化は次のように解釈するの が妥当であろう. 即ち, 隶河の融解がチーラ河の流 豆の多くの部分を占めている，このため, 日中の気 温が一定の高さ以上になる夏の日に河川流量は顥著 な日変化を示す.この解釈は図一 4 に示された河川 流量が降水量に大きくは依存せず 7,8 月に最も多 いこととも矛盾しない.

\section{I. おわりに}

タクラマカン砂漠周辺での水文環境についてその 概要を記し, 砂漠に流入する一小河川であるチーラ 河について，氷河を起源とする河川の流出特性をみ た.

氷河を起源とする河川で融解が河川流量の多くの 部分を占めているならば, また地球温暖化がこの地 域で降水量の増加をもたらさないならば, 地球温暖 化は短期的には流量の増加をもたらすが，長期的に は水資源の減少を生じることになる，タリム盆地の いくつかの河川流量の経年変化を調べた結果では, 氷河を主な水源とする河川では流量が増加, 降雨を 主な水源とする河川では流量が減少，という傾向が 認められている (Tang, 1992)。これと同時に，この 地域では1940年頃から気温が上昇していること (Ling, 1990)，テンシャン山脈にある氷河が1980年 代に著しく縮小したこと等（Shi and Ren, 1990）が 報告されており，この様な地域での水河を含む水文 気象の観測は，この地域の水資源の面みならず気侯 変化の監視の面からも重要となってくるのではない
かと思われる。

睞辞：本文をまとめるにあたり，視点と発表の機会 を与えて下さった本誌編集委員村上雅博博士に感謝 致します，なお，チーラ河の流出特性等は，科学技 術振興調整費「砂漠化機構の解明に関する国際共同 研究」の成果の一部であることを記しておきます.

\section{参考文献}

Gao Qianzhao et al., (1992): Water resources in the arid zone of Northwest China, J. Desert Research, 12, No.4, pp. 1-12 (中国語).

李寶興・趙運昌（1965）：塔里木盆地的地下水及其形 成条件. 治砂研究 No.6.

Ling Yuquan (1990): The climatic characteristics and its changing tendency in the Taklimakan Desert, $J$. Desert Research, 10, No. 2, pp. 9-19 (中国語).

Shi Yafeng and Ren Jiawen, (1990): Glacier recession and lake shrinkage indicating a climatic warming and drying trend in Central Asia, Annals of Glaciology, 14, pp. 261-265

Tang Qicheng, 1992: Recent tendency analysis of river discharge in Tarim Basin, J. Desert Research, 12, No. 2, pp. 15-20 (中国語).

The 21 (1993)：8 兆トン タクラマカン砂漠の埋 藏水, 8 月号, p. 9 .

Yonetani, T., T. Kimura and Wang Lian Way (1993): Run-off characteristics in the Cele River basin, Japan-China intermational sympo. sium on the study of the mechanism of desertification, pp. 8-2 


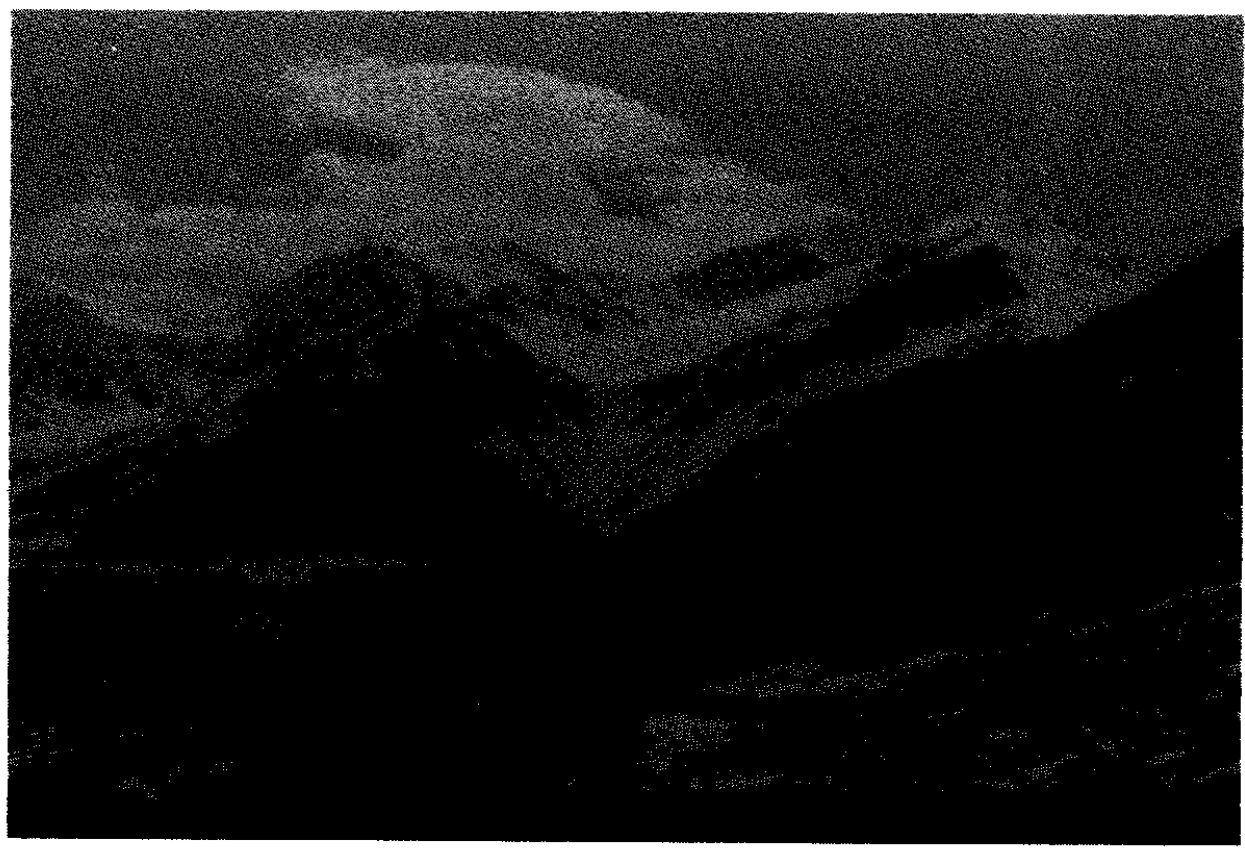

中国タクラマカン盆地よクチーラ河原流城の山岳水河を息む

(王良䞍・中国科学院，1993年 9 月撮影) 